\title{
Cytological Parameters of Cotton Plants under Infestation of the Two Spotted Spider Mite, Tetranychus urticae Koch (Acari: Tetranychidae)
}

\author{
Ghada S. Refaei \\ Plant Protection Research Institute, ARC, Dokki, Giza, Egypt, Dr_ghadasalah@yahoo.com.
}

\begin{abstract}
This study was conducted to evaluate the ultrastructure and the scheme of cellular events occurring to cotton plant leaves after Tetranychus urticae infestation. Complementary information at the ultra-structural level were essential to provide further insight into the biological significance of the mite infestation. Data from the light and electron microscope examination of thin cross sections of cotton plant leaves under infestation with Tetranychus mites revealed different cytological modifications including mesophyll cell wall alteration, cytoplasm breakdown, and necrosis of cell and deformation which caused severe reductions in stomatal conductance \& photosynthesis rate. Where, examination of light micrographs and ultrastructure thin cross sections of uninfested cotton plant (control) indicated the regular distributions of most cells and density in staining of most inter-cellular spaces and cell walls.
\end{abstract}

Key words: Two-spotted spider mite, Tetranychus urticae, Cotton, Scanning electron microscope, Stomatal conductance, Photosynthesis

\section{INTRODUCTION}

The two-spotted spider mite, Tetranychus urticae Koch (Acari: Tetranychidae) is one of the most common mites infesting economic crops. It heavily damages the crops and brought loss to agriculture production. It feeds primarily on leaf surfaces, pierces plant tissue and disrupts mesophyll cells underlying the epidermis (Bondada et al., 1995). Although various aspects of plant reactions to mites and acaricide resistance have been studied (Helle and Sabelis, 1985; Brody and Karban, 1989; Bondada, 1994; Benhamou and Lafontaine, 1995; Benhamou and Belanger, 1998; Ferriera et al., 2015), still little has been reported about the scheme of cellular events occurring to leaves after Tetranychus infestation.

Therefore, the aim of this study was to illustratethe potential and ultra structure outcome of Tetranych usurticae infestation damages in cotton plants.

\section{MATERIALS AND METHODS}

These experiments were conducted using cotton plants, season 2013. Plants were grown under irrigated field conditions at Giza governorate.

Plants were grown in split plot with three replications combined. Cotton seeds (Giza 85) varity were cultivated on March. Fertilization program had been done according to the recommended doses throughout the growing season. All plants were well watered throughout the season.

Treatments consisted of uninfected plants (control) that kept mite free by periodic application of acaricide (Bethke et al., 2004).

Mites were reared on green beans (Phaseolus vulgaris L.) in a greenhouse. High mite populations were allowed to increase infestation. A symptoms of mite damages were observed. Leaves from control and mite infested plants were collected for cytological and ultrastructure processing (light and electron microscope).

Tissue processing for electron microscope studies:

The work was carried out in TEM lab (CURP) Cairo University Research Park, Faculty of agriculture, Cairo University. Leaf tissues were fixed by the method described by (Rocchetta et. al., 2007).Tissue samples were sliced into $\sim 1 \mathrm{~mm}$ slices in $2.5 \%$ glutaraldehyde fixative with $0.1 \mathrm{M}$ sodium phosphate buffer (pH7.4). Fixative was removed, and the tissue sample was washed with sodium phosphate buffer three times for 30 min each. The buffer was removed and $1 \%$ osmium-tetroxide $\left(\mathrm{OsO}_{4}\right)$ was added to the tube and allowed to sit 3 hours at $4{ }^{\circ} \mathrm{C}$. Then, the osmium fixative was removed, and samples dehydrated in an ethanol series and embedded in an epoxy resin. Microtome sections prepared at approximately 500-1000 $\mu \mathrm{m}$ thickness with a Leica Ultra cut UCT ultra microtome. Thin sections were stained with toluidine blue (1X) then sections examined by camera Lica ICC50 HD. Ultra-thin sections were prepared at approximately $75-90 \mu \mathrm{m}$ thickness and stained with uranyl acetate and lead citrate, then examined by transmission electron microscope JEOL (JEM-1400 TEM) at the candidate magnification. Images were captured by CCD camera model AMT, optronics camera with 1632 x 1632 pixel. An average of five samples were investigated for each treatment from different plants. For each sample 10 ultrathin sections were examined under light and electron microscope.

\section{RESULTS AND DISCUSSION}

The tetranychid mites, Tetranychus urticae Koch (Acari: Tetranychidae) heavily damaged several 
crops by feeding primarily on leaves. Little has been reported about the scheme of cellular events occurring to leaves after Tetranychus infestation. Complementary information at the ultra-structural level were essential to provide further insight into the biological significance of the Tetranychus urticae in cotton plants.

Therefore, the aim of this study was to illustratethe potential and ultrastructure outcome of Tetranychus urticae infestation damages in cotton plants

Data in figure (1B) showed the Light microscope examination of thin cross sections of cotton plant leaves under mite infestation. This examination reported different cytological changes in mite infected leaves such as a mesophyll cell wall alteration, cytoplasm breakdown, necrosis of cell and organelle destruction which caused rapid and severe reductions in photosynthetic rate, stomatal conductance and transpiration efficiency (Helle and Sabelis, 1985; Bondada et al., 1995; Reddall et al., 2004). As a result, a significant yield loss was observed compared to the control.

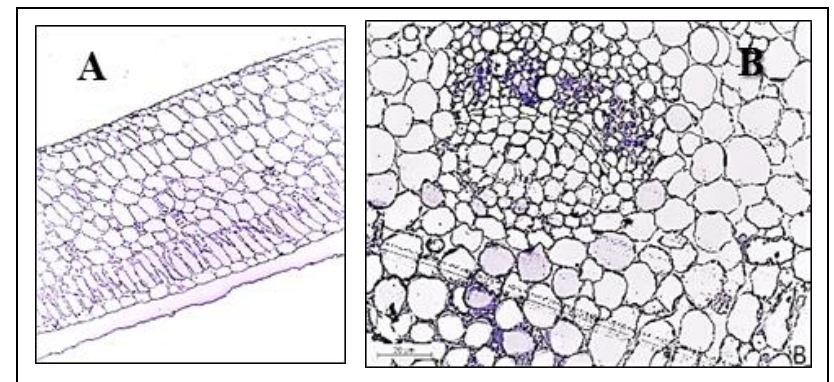

Fig. (1). Light micro graphs of samples from:

A- Un-infested cotton leaves $(\mathrm{Bar}=200 \mu \mathrm{m})$

B- Tetranychus urticae infested cotton leaves (Bar $=20 \mu \mathrm{m})$.

Electron micrographs cross section of plant leaves under the infestation with the $T$. urticae reported different cytological modification (Fig. 2A, B \& C), extensive cell disorganization and disruption, reduction in density of wall and extensive cell disorganization and disruption. The chloroplasts of spongy mesophyll cells were deformed, and the grana disintegrated (Fig. 2C). A similar observation was recorded by (Bondada et al., 1995) in mites infested leaves reported that $T$. urticamite secreted a toxin during feeding which led to a swollen of chloroplasts with a large plastglobuli and disintegrated grana. However, Examination of light micrographs and ultrastructure thin cross sections of uninfested cotton plant (control) (Figs.1A \& $2 \mathrm{E} \& \mathrm{~F}$ ) indicated the regular distributions of most cells and density in staining of most inter-cellular spaces and cell walls (O'Brien and McCully, 1981; Benhamou and Lafontaine, 1995; Benhamou and Belanger, 1998).
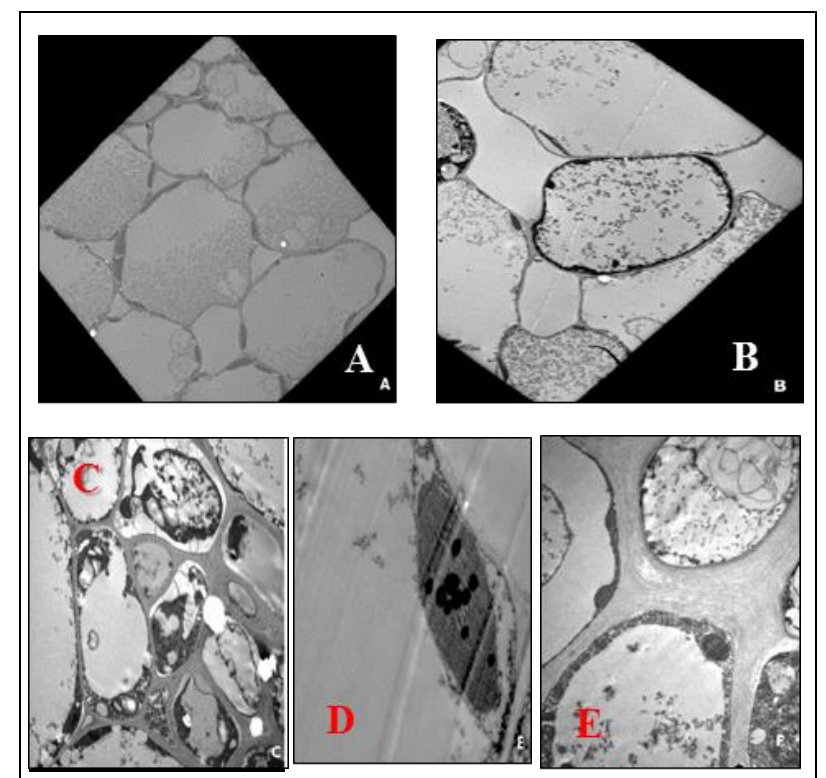

Fig. (2) Transmission electron micrograph of a) samples taken from leaves infested with Tetranychus urticae (A-c), A, Bar=10 microns \& $\mathrm{B}-\mathrm{C}, \mathrm{Bar}=2$ microns, showing extensive cell disorganization and host cell wall alterations. b) Samples taken from control cotton plant (E\&F). E, Bar $=500 \mathrm{~nm} \& \mathrm{~F}$, Bar=2 microns.

Results from this experiment suggest that cotton and other crops should be protected from spider mite infestation. Therefore, continued research is needed to understand how outbreaks of spider mites on cotton development and the duration of infestation will affect the yield

\section{REFERENCES}

Benhamou, N. and Lafontaine, P. J. 1995. Ultrastructural and cytochemical characterization of elicitor-induced responses in tomato root tissues infected by Fusarium oxysporum f. sp. radicislycopersici. Planta.197:89-102.

Benhamou, N. and Belanger, R. 1998. Induction of systemic resistance to Pythium damping-off in cucumber plants by benzothiadiazole: ultrastructure and cytochemistry of the host response. The plant Journal 14(1), 13-21.

Bethke, J; Siapno, O. and Redak, R. 2004. The latest miticides. Greenhouse Product News 14: 54-56.

Bondada, B. R. 1994. Late season canopy photosynthesis and foliar nitrogen fertilization of cotton Ph.D. thesis, University of Arkansas, AR, USA. Pp.99-125.

Bondada, B. R.; Oosterhuis, D. M.; Tugwelf, N. P. and Kim, K. S. 1995. Physiological and cytological studies of two spotted spider mite, Tetranychus urticae K., injury in cotton. Southwestern Entomologist. 20(2), 171-180.

Brody, A. K. and Karban, R. 1989. Demographic analysis of induced resistance against spider mites 
(Acari: Tetranychidae) in cotton. J Econ Entomol 82:462-65.

Ferreira, Cecilia B.S.; Fernanda, H.N.; Rodriguez, A.R.S.; Siqueira, H. A.A. and Gondim, M.G.C. 2015. Resistance in field populations of Tetranychus urticae to acaricides and characterization of the inheritance of abamectin. Crop Prot. 67, 7783.

Helle, W. and Sabelis, M. W. 1985. Effects on the host plant. Spider mites, their biology, natural enemies, and control. In World crop pests. Vol. IA. pp. 238-321.
O'Brien, T. P. and McCully, M. E. 1981. The Study of Plant Structure: Principles and Selected Methods. Termarcarphi, Melbourne, Pty, [2], x, 20, 52, 30, 56, 14, 104, xxvi, Australia, 46 pp.

Reddall, A.; Sadras, V. O.; Wilson, L. J. and Gregg, P. C. 2004. Physiological Responses of Cotton to Two-Spotted Spider Mite Damage. Crop Sci. 44:835-846.

Rocchetta, I.; Leonard, P.I.; Filho, G.M.A, 2007. Ultrastructureand $\mathrm{x}$-ray microanalysis of Euglena gracilis(Euglenophyta) under chromium stress. Phycologia, 46: 300-306. 